\begin{tabular}{|c} 
Ambiente \& Água - An Interdisciplinary Journal of Applied Science \\
ISSN 1980-993X - doi:10.4136/1980-993X \\
www.ambi-agua.net \\
E-mail: ambi.agua@gmail.com
\end{tabular}

\title{
Potential for biogas generation from sweet potato genotypes
}

\author{
ARTICLES doi:10.4136/ambi-agua.2317
}

Received: 22 Aug. 2018; Accepted: 18 Dec. 2018

\author{
Samantha de Paula Batista ${ }^{1 *}$; Edson Perez Guerra ${ }^{2}$; \\ Juliano Tadeu Vilela de Resende ${ }^{2}$; ; Matheus Vitor Diniz Gueri ${ }^{3}{ }^{(D}$; \\ Guilherme Campos Carvalho ${ }^{\oplus}$; Jessica Naiara dos Santos Crestani2 ${ }^{\circledR}$; \\ Israel Felipe Lustosa da Silva ${ }^{2}$ iD

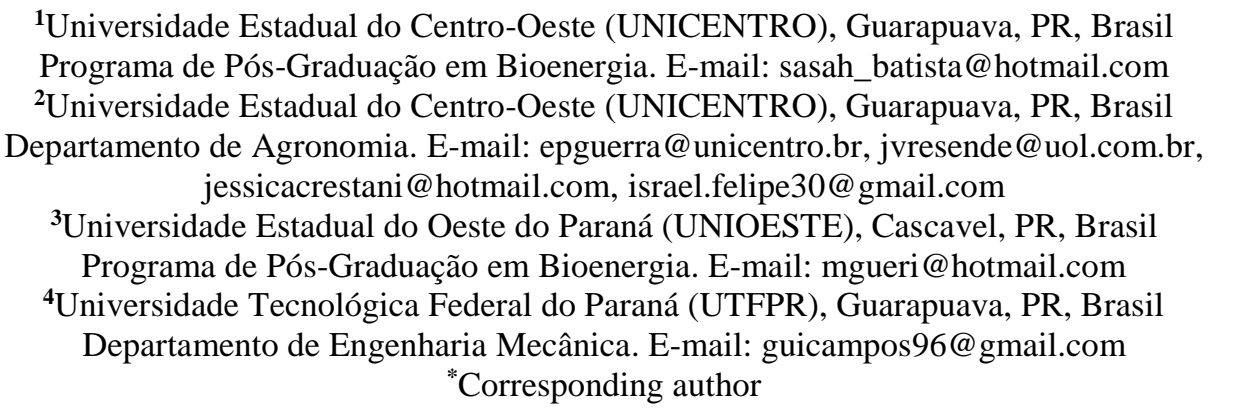

\section{ABSTRACT}

Biogas is a technology that enables the generation of energy through the process of anaerobic biodigestion, and sweet potato is an option as an energy production source. This research evaluated biogas production in anaerobic biodigesters and characterized the physicochemical composition of two commercial sweet potato cultivars, BRS Cuia and BRS Rubissol, and two genotypes, Bela Vista and Laranjeiras. Variance analysis, the Tukey test and the physical-chemical characterization were completed, and the results were correlated using principal component analysis (PCA). In the analyses of tuberous root composition, significant differences between the genotypes were observed because of the influence of the absorption of moisture, decomposition, and variations in the yield and quality of roots. For the biochemical methane potential (BMP) test, the estimate of biogas production was 2,906.5 liters ha-1 for the cultivar BRS Cuia, 2,712.4 liters ha ${ }^{-1}$ for Laranjeiras, 2,906.5 liters ha ${ }^{-1}$ for BRS Rubissol, and 398,2 liters ha ${ }^{-1}$ for Bela Vista. The PCA analysis of sweet potato genotypes, physical-chemical and agronomic parameters showed all genotypes have a direct correlation with the amount of reducing sugars and humidity, with $97.77 \%$ of the data variability explained. The Laranjeiras genotype has the most significant potential to produce biogas, followed by the BRS Cuia cultivar. The results emphasize that the sweet potato crop is a good source of biomass for energy generation.

Keywords: biodigester, bioenergy, Ipomoea batatas L.

\section{Potencial de geração de biogás de genótipos de batata-doce}

\section{RESUMO}

O biogás é uma tecnologia que possibilita a geração de energia através do processo de biodigestão anaeróbia, sendo uma opção a produção a partir de batata-doce como fonte 
energética. A presente pesquisa teve por objetivo avaliar a produção de biogás em biodigestores anaeróbios de bancada, caracterizar os parâmetros físico-química das cultivares de batata-doce BRS Cuia e BRS Rubissol e dos genótipos Bela Vista e Laranjeiras. Foi feita análise de variância, teste Tukey e correlação com a caracterização físico-química dos genótipos por análise de componentes principais (ACP). A partir das análises da composição das raízes tuberosas, foram observadas diferenças significativas entre os genótipos, devido a influência na absorção da umidade, decomposição, ocorrendo variações na produtividade e qualidade das raízes. Para os ensaios do potencial bioquímico de metano (BMP - biochemical methane potential) a estimativa de produção de biogás foi de $2.906,5 \mathrm{~L} \mathrm{ha}^{-1}$ para a cultivar BRS Cuia e de 2.712,4 L ha ${ }^{-1}$ para Laranjeiras, de 2906,5 L ha ${ }^{-1}$ para BRS Rubissol e de 398,2 $\mathrm{L} \mathrm{ha}^{-1}$ para Bela Vista. A partir da ACP com a produção de biogás dos genótipos de batata-doce, dos parâmetros físico-químicos e agronômicos, foi possível identificar que todos os genótipos têm correlação direta com a quantidade de açúcares redutores e umidade, com explicação de 97,77\% da variabilidade dos dados, e que o genótipo Laranjeiras foi o que apresentou maior potencial significativo em produzir biogás, seguido da BRS Cuia. Diante dos resultados obtidos enfatizase a cultura da batata-doce como fonte de biomassa para a geração de energia.

Palavras-chave: biodigestor, bioenergia, Ipomoea batatas L.

\section{INTRODUCTION}

The sweet potato (Ipomoea batatas L.) is a herbaceous plant native to Central and South America. It is adapted to the tropical and subtropical climate, presenting favorable characteristics such as low production cost, resistance to pests, wide adaptation in degraded soils, prolonged harvest, being considered a rustic crop (Miranda et al., 1995; Silva et al., 2008; Stathers et al., 2013).

Biomass is a renewable source of energy that can generate heat, electricity and biofuels (McKendry, 2002). With the expansion of clean and renewable energy, the production of biofuel from the biomass of several crops has been used, since they contain high content of organic matter from the carbohydrates (sugars and starches) stored (Brasil, 2015). Among the biomass used are: sugarcane, corn, oats, manioc, castor bean, pine, sugar beet, sunflower, potato (Silveira, 2008).

The sweet potato genotypes differ in many aspects, such as root structure, root shape, reserve root bark color, pulp color, flavor, texture, resistance to pests and yields (Borém, 2005). These characteristics are important in deciding which variety to use for trade and for other processing (Stathers et al., 2013).

In the harvest period of the sweet potato, losses of tuberous root can occur in the field, in the process of washing, grading, packaging and transport, or even in market wholesale, retail and with the consumer. When the tuberous root is considerably depreciated and does not meet the aesthetic standards of market quality, such as showing small or very large deformities, part of the harvest is destined to animal feed or become waste and is sent to landfills or even left in the field (Chitarra; Chitarra, 2005). One way to take advantage of these sweet potato tailings would be to use their biomass energetically through the anaerobic process to obtain biogas (Brasil, 2015).

Sweet potatoes have high potential as an energy source in the production of ethanol and biogas. In an experiment conducted at a small industrial plant in Palmas, Tocantins, Brazil, Silva et al. (2018) obtained a high yield of sweet potato bioethanol of $161.4 \mathrm{~L} \mathrm{t}^{-1}$ corresponding to $10,598 \mathrm{~L} \mathrm{ha}^{-1}$, based on the productivity of $65.5 \mathrm{t} \mathrm{ha}^{-1}$ of the evaluated cultivar. They considered the result $46 \%$ superior to the ethanol yield of sugarcane, $34 \%$ superior to that of 
sugar beet and $149 \%$ superior to that of corn ethanol. For biogas production, however, research work is needed to determine the potential for energy production from the sweet potato.

The process of anaerobic bio-digestion is the biological conversion of organic matter in the absence of oxygen. There are four phases: hydrolysis, acidogenesis, acetogenesis and methanogenesis transforming into biogas, consisting mainly of methane and carbon dioxide. This process occurs in biodigesters, structures designed and constructed from a closed chamber where the organic material is deposited and undergoes decomposition, generating the biogas (Yu; Schanbacher, 2010; Zhang et al., 2018).

In Brazil the most-used models of biodigesters are the Indian, tubular and Chinese, considered the oldest of those for agricultural use. With the use of biodigesters in expansion, several models have been proposed and the technology is being adapted to the needs of the field and for sanitary treatment (Deganutti et al., 2002).

In this context, biogas is a technology that enables solutions to problems such as the production of alternative energy, the safe management of human, animal, municipal and industrial waste and the control of environmental contamination (Xumeng et al., 2014).

\section{MATERIALS AND METHODS}

The BRS Cuia and BRS Rubissol sweet potato cultivars developed by Embrapa Clima Temperado (Pelotas, RS) and the Bela Vista and Laranjeiras genotypes were selected for the experiment and come from the germplasm bank of the Horticulture Research Center.

Samples of the four sweet potato genotypes were placed in a drying oven at $60^{\circ} \mathrm{C}$ for approximately eight hours. Flour was obtained by grinding and sieving, and stored in polyethylene bags packed in a vacuum to avoid contamination. The characterization parameters were moisture, acidity, $\mathrm{pH}$, starch, and reducing sugars for sweet potato genotypes (Cecchi, 2003; IAL, 2008).

The presence of inoculum benefits the biodigestion process of the raw material, improving the methane content in the biogas composition (Xavier et al., 2010; Hassan et al., 2017). Cattle manure inoculum was collected and transported in borosilicate vials and kept under refrigeration conditions at $10^{\circ} \mathrm{C}$. This material presented $72.68 \%$ humidity and $\mathrm{pH}$ of 5.93 , characterized according to AOAC (2007).

According to Azevedo (2010), it is necessary to dilute the inoculum in a solution of mineral salts in a 1:1 ratio. The mineral salt solution was prepared using $1.0 \mathrm{~L}$ of distilled water with $2.0 \mathrm{~g}$ of potassium dibasic phosphate $\left(\mathrm{K}_{2} \mathrm{HPO}_{4}\right) 20 \mathrm{~g}$ of potassium phosphate monobasic $\left(\mathrm{KH}_{2} \mathrm{PO}_{4}\right)$ and $3.5 \mathrm{~g}$ of urea $\left(\mathrm{NH}_{2} 2 \mathrm{CO}\right)$. After the addition of the salts, the solution was homogenized with the cattle manure inoculum and samples of the sweet potato genotypes were added. Subsequently, they were transferred to the biodigesters until the volume of $150 \mathrm{~mL}$ was completed for $250 \mathrm{~mL}$ glass vials.

\subsection{Laboratory tests to obtain biogas}

The anaerobic biodigesters was monitored by means of the biochemical methane potential (BMP) tests, which measure the biodegradability of organic matter through total methane production (Gueri, 2018). Nine lab bench biodigesters were used (Figure 1). 


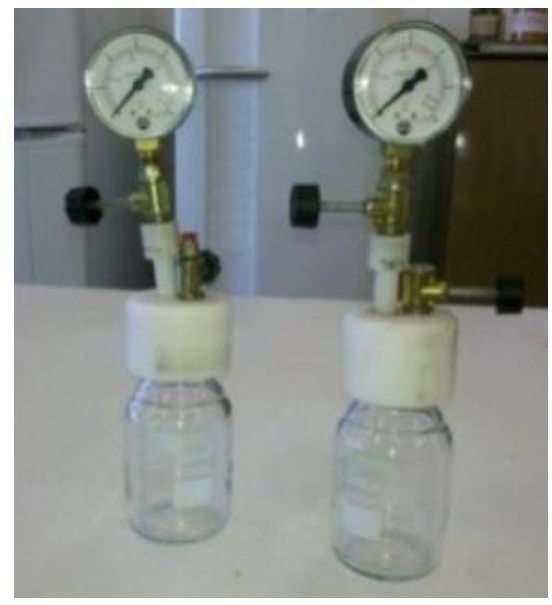

Figure 1. Bench scale anaerobic biodigesters (Personal Archive, 2016).

\subsection{Preparation of biodigesters}

The bench anaerobic biodigesters were assembled using BMP assays. Each biodigester was composed of $250 \mathrm{~mL}$ borosilicate vials, with a nylon screw cap, containing a gas outlet valve and a valve with manometer for the internal pressure monitoring (Figure 1).

Two treatments were used for the tests:

Treatment 1: Raw material + Inoculum, composed of $50 \mathrm{~g}$ of sweet potato flour inoculated with $20 \mathrm{~g}$ of bovine manure diluted in $20 \mathrm{~g}$ of salt solution;

Treatment 2: only inoculum in biodigester as control (white) composed of $20 \mathrm{~g}$ of bovine manure.

After inoculation, the moisture content obtained from the substrate with the genotypes was 83.3\% for Bela Vista, 79.18\% for Laranjeiras, $76.08 \%$ for BRS Cuia and 83.28\% BRS Rubissol. The screw caps were fixed in the vials and a stream of nitrogen gas was circulated into the headspace of each biodigester for about four minutes to ensure anaerobiosis of the medium.

\subsection{Test Monitoring BMP}

The biogas volume generated was measured by the U-liquid column type manometric method, by reading of the liquid column coupled in the biodigesters.

The experiment was installed into a BOD Illumination Incubator Automatic, with lights turned off, to have constant temperature of $36^{\circ} \mathrm{C}$, monitored daily; the local atmospheric pressure (National Institute of Meteorology - INMET) was monitored every six hours.

The internal pressure of the flasks was converted into volume of the generated biogas by Equations 1 and 2, for the different sweet potato genotypes evaluated and transformed to the normal conditions of temperature and pressure (CNTP) (Harries et al., 2001). This procedure was performed by Alves (2008), Gueri (2018), recommended by Angelidaki et al. (2009) and reported by Alzate et al. (2012).

Volume of biogas generated between $T+(T+1)=\frac{[\mathrm{PF}(\mathrm{mbar}) \cdot \mathrm{VUF}(\mathrm{L}) \cdot 22,42] \cdot 1000]}{[83,14 \cdot T F(K)]}$

Where: $\mathrm{T}=$ time $($ days $) ; \mathrm{PF}(\mathrm{mbar})=$ bottle pressure in millibar; VUF $(\mathrm{L})=$ useful volume of the bottle in liters; $\mathrm{TF}(\mathrm{K})=$ bottle temperature in Kelvin.

Volume of accumulated biogas $(m L)=[$ Generated betweenT $+(T+1)]+V G A(m L)$ 
Where: $\mathrm{T}=$ time (days); VGA $(\mathrm{mL})=$ volume of accumulated biogas from the previous day in milliliters.

\subsection{Statistical analysis}

The physico-chemical analyzes and the BMP tests of the biogas production process were submitted to Analysis of Variance (ANOVA), to the Tukey test $(p<0.05$ ) of the means significant differences, and the correlation with the physicochemical characterization of the genotypes by the principal components analysis (PCA). The statistical program Minitab17 was used.

\section{RESULTS AND DISCUSSION}

\subsection{Physico-chemical characterization}

The flour of sweet potato genotypes was characterized for physicochemical composition (Tables 1 and 2).

Table 1. Summary of physical-chemical variance analyzes of flour of sweet potato genotypes.

\begin{tabular}{lccccccc}
\hline \multicolumn{7}{c}{ Means Square } \\
\hline Variation of source & GL & Moisture & Acidity & Starch & R.S. & pH & Ashes \\
\hline Block & 2 & 0.03331 & 0.00212 & 0.02083 & 0.12 & 0.00033 & 0.19341 \\
Genotypes & 3 & $36.8768^{* *}$ & $0.0498^{* *}$ & $66.6244^{* *}$ & $2.996389^{* *}$ & $0.0123^{* *}$ & $0.7120^{*}$ \\
Residue & 6 & 0.04181 & 0.00203 & 0.1492 & 0.101667 & 0.00075 & 0.1149 \\
Total & 11 & - & - & - & - & - & - \\
CV $(\%)$ & & 2.63 & 4.69 & 1.89 & 5.99 & 0.45 & 10.90 \\
\hline
\end{tabular}

*, ** significant at the level of $5 \%$ and $1 \%$ of probability, $(\mathrm{p}<0.05)$ and $(\mathrm{p}<0.01)$, respectively; R.S. (Reducing Sugars); CV (coefficient of variation).

Table 2. Means of physical-chemical parameters in sweet potato genotypes.

\begin{tabular}{lcccc}
\hline Parameters $^{1}$ & Bela Vista & BRS Cuia & BRS Rubissol & Laranjeiras \\
\hline Moisture (\%) & $10.62 \mathrm{a}$ & $3.40 \mathrm{c}$ & $10.60 \mathrm{a}$ & $6.50 \mathrm{~b}$ \\
Acidity (\%) & $1.09 \mathrm{a}$ & $1.04 \mathrm{a}$ & $0.84 \mathrm{~b}$ & $0.85 \mathrm{~b}$ \\
pH & $5.99 \mathrm{~b}$ & $6.12 \mathrm{a}$ & $6.10 \mathrm{a}$ & $6.00 \mathrm{~b}$ \\
Starch (\%) & $53.04 \mathrm{~b}$ & $67.60 \mathrm{a}$ & $37.69 \mathrm{c}$ & $30.30 \mathrm{c}$ \\
Reducing sugars (\%) & $3.70 \mathrm{c}$ & $4.30 \mathrm{~b}$ & $2.92 \mathrm{~d}$ & $4.49 \mathrm{a}$ \\
Total sugar & $56.73 \mathrm{~b}$ & $71.90 \mathrm{a}$ & $40.61 \mathrm{c}$ & $34.79 \mathrm{c}$ \\
Ashes (\%) & $2.78 \mathrm{~b}$ & $3.17 \mathrm{ab}$ & $2.70 \mathrm{~b}$ & $3.77 \mathrm{a}$ \\
\hline
\end{tabular}

Means followed by the same letter in row do not differ statistically from each other by the Tukey test $(\mathrm{p}<0.05) ;{ }^{1} \mathrm{n}=$ three replicates.

According to the Technical Regulation for Setting Identity and Quality Standards for Tubers, the sweet potatoes samples were within the maximum range of $2.0 \%$ of titratable total acidity desirable (Table 2). So, when acidity is decreased, the fermentation intensity decreased and the processing time increased (Brasil, 1978).

The flour purity index is measured by the ash percentage. A high ash content will indicate more minerals present. The values obtained (Table 2) were similar to those found by Lima et al. (2001), with an averaged of $2.0 \%$.

According to Alves (2008), the ideal $\mathrm{pH}$ for anaerobic digestion should be in the 6.3 to 7.8 range, which demonstrates greater efficiency of the methanogenic phase. Considering the $\mathrm{pH}$ values obtained (Table 2), it was lower than ideal, and the process could be more efficient. 
The moisture obtained for the sweet potato flour (Table 2) was similar to that found by Borba et al. (2005), 8.7\%, considering an average value of the cultivars.

Sugar levels are variable due to cultivar, growing season, climate and storage time, and because the starch over time is converted to simple sugars. The values obtained in sweet potato flour (Table 2) were similar to those of Silva et al. (2008), who established values of 4.8 to $7.8 \%$ without specifying the cultivar.

The starch is the main component of dry matter of the sweet potato tuberous roots $(66.8$ $78.5 \%$ ) followed by soluble sugars $(8.2-15.3 \%)$ which represent 6.17 to $7.69 \%$ of the total dry matter (Kohyama; Nishinari, 1992). The values obtained in sweet potato flour (Table 2) were similar to those of Borba et al. (2005), who established values of $51.8 \%$ starch without specifying the cultivar.

\subsection{Assay of the biochemical potential of methane (BMP)}

After calculations (Equations 1 and 2), a biogas production profile graph was generated for each genotype over time. It is observed that they were very different from the inoculum used as control (Figure 2). The daily production of biogas varied for days of incubation and for sweet potato genotypes, making it necessary to check the production at each hour of the day, for five consecutive days.
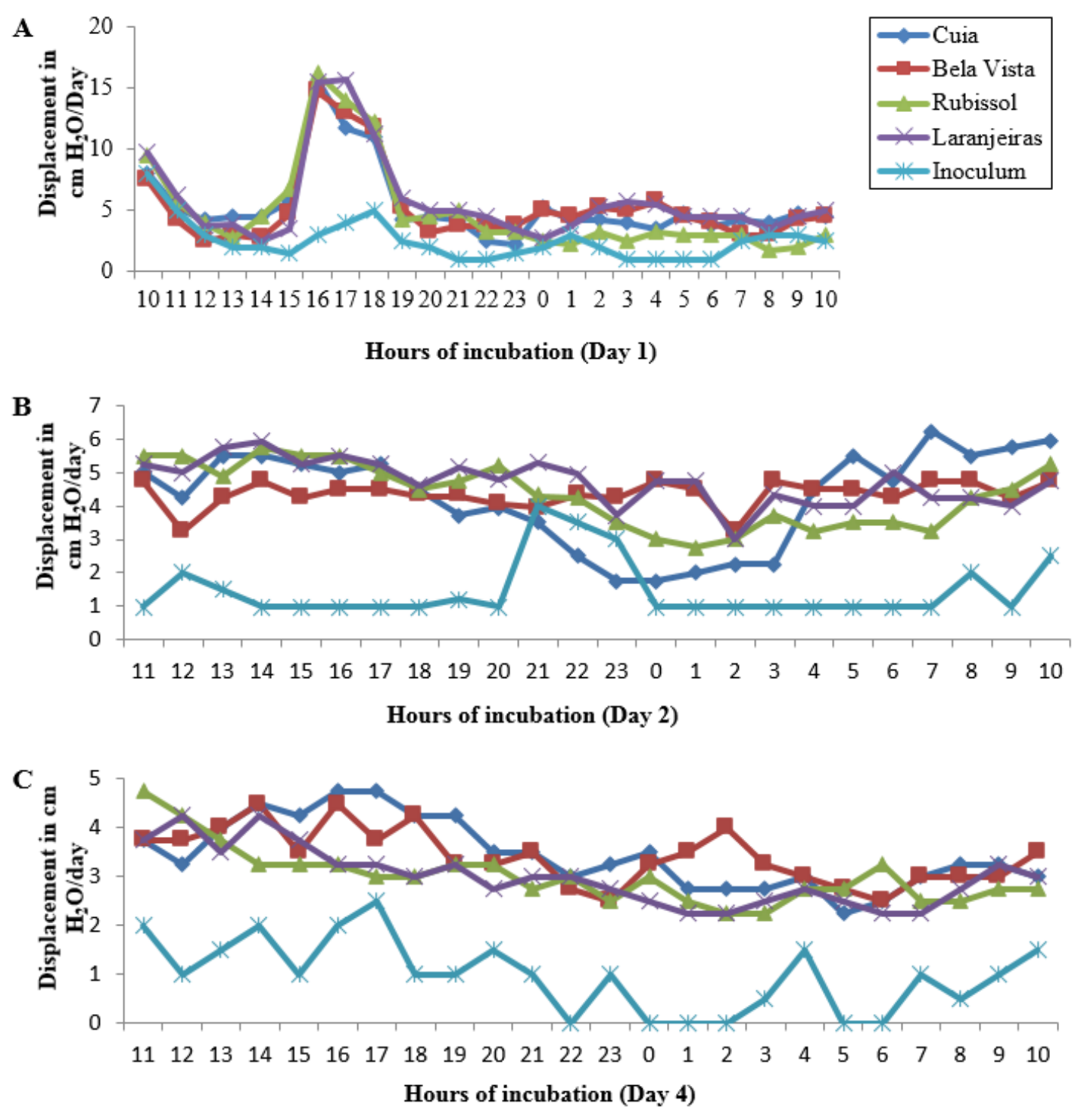

Rev. Ambient. Água vol. 14 n. 2, e2317 - Taubaté 2019 

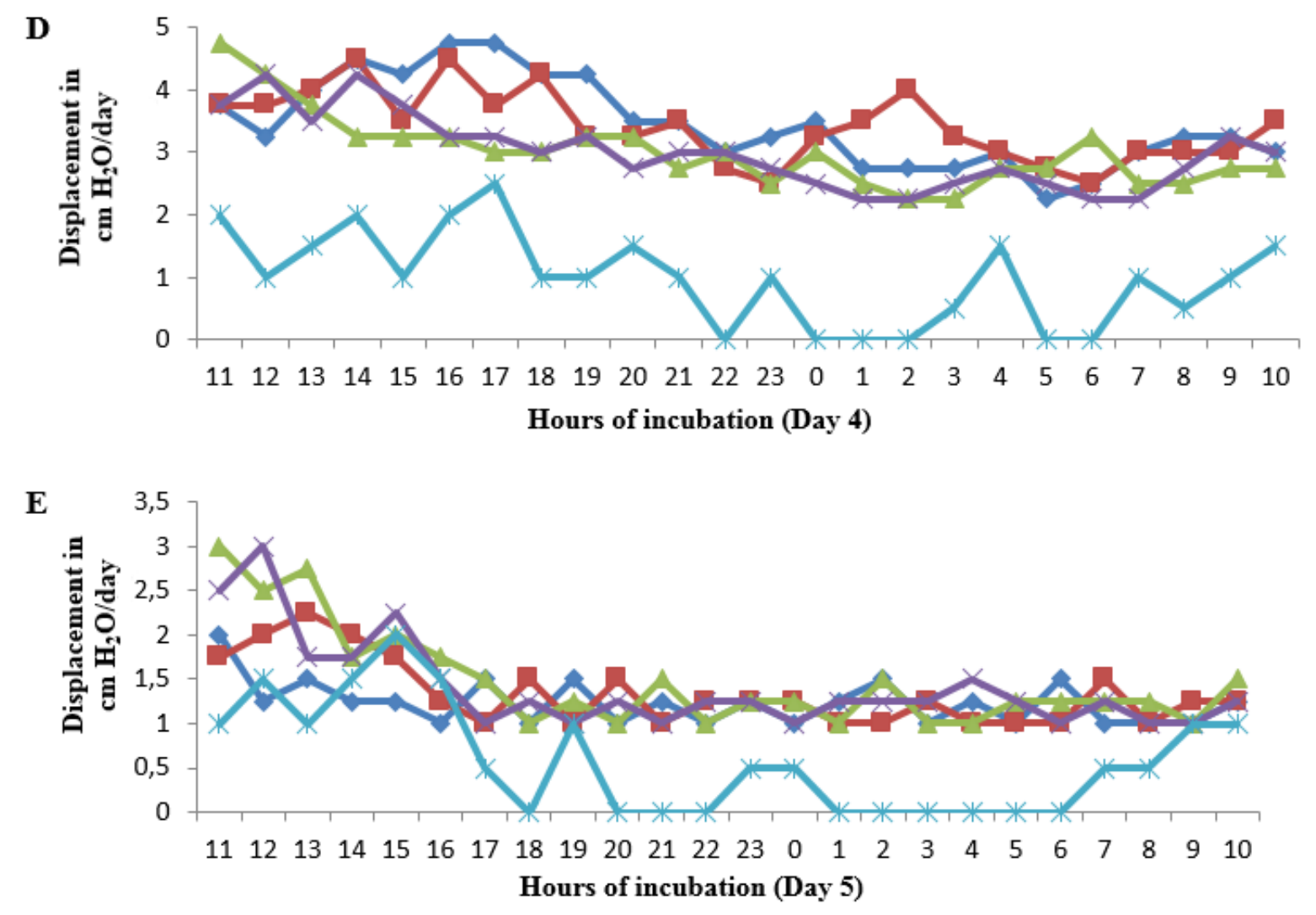

Figure 2. Profile of biogas production of sweet potato genotypes every hour from first day to fifth day (2A to $2 \mathrm{E})$.

From the inoculums incubation, there were different production peaks in the process of anaerobic biodigestion, as observed between the 16h-18h (Figure 2A), due to physicochemical factors such as $\mathrm{pH}$, sugars and atmospheric pressure. The temperature was kept constant at $\pm 36^{\circ} \mathrm{C}$.

However, it was necessary to monitor the biogas production test every hour as observed in Figures $2 \mathrm{~A}$ to $2 \mathrm{E}$, as the sweet potato undergoes the biodigestion process rapidly, consuming its simple sugars, since no hydrolysis was performed to test the carbohydrate reserve of the starch. This justifies the different displacement reading peaks that occurred each day. Schirmer et al. (2014) obtained similar results, with peak generation of biogas reached in the first five days of the experiment.

\subsection{Biogas generation}

The generated and accumulated average volume of biogas produced during the incubation period is shown in Table 3. The atmospheric pressure was measured every six hours during the test period. The values of the internal pressure of the bottles, by displacing the bubble in the hose column, were converted into the volume of biogas generated by means of Equations 1 and 2 and transformed to the normal conditions of temperature and pressure (CNTP).

The maximum daily rate of biogas production was reached on the first monitoring day (Figure 3A); this chart shows the daily accumulated biogas volume of the four sweet potato genotypes and for the inoculum (control).

\section{IPABH}


Table 3. Biogas production of sweet potato genotypes with water column displacement measurement every hour for five days, with calculation of CNTP.

\begin{tabular}{|c|c|c|c|c|c|c|}
\hline \multirow[b]{2}{*}{ Day } & \multicolumn{6}{|c|}{ Biogas production } \\
\hline & $\begin{array}{c}\mathrm{SDC} \\
\left(\mathbf{c m ~ \mathrm { H } _ { 2 } \mathrm { O } )}\right)\end{array}$ & $\begin{array}{c}\text { CNTP } \\
\text { Ger. }(\mathrm{mL})\end{array}$ & $\begin{array}{c}\text { CNTP } \\
\text { Ac. }(\mathbf{m L})\end{array}$ & $\begin{array}{c}\mathrm{SDC} \\
\left(\mathbf{c m ~ \mathrm { H } _ { 2 } \mathrm { O } )}\right)\end{array}$ & $\begin{array}{c}\text { CNTP } \\
\text { Ger. (mL) }\end{array}$ & $\begin{array}{c}\text { CNTP } \\
\text { Ac. }(\mathrm{mL})\end{array}$ \\
\hline & \multicolumn{3}{|c|}{ BRS Cuia } & \multicolumn{3}{|c|}{ BRS Rubissol } \\
\hline 1 & 135.85 & 9.80 & 9.80 & 125.60 & 9.06 & 9.06 \\
\hline 2 & 102.15 & 7.65 & 17.83 & 104.15 & 7.80 & 17.21 \\
\hline 3 & 83.00 & 6.02 & 23.29 & 72.50 & 5.26 & 21.93 \\
\hline 4 & 29.50 & 2.13 & 25.29 & 35.50 & 2.56 & 24.37 \\
\hline \multirow[t]{2}{*}{5} & 8.50 & 0.64 & 27.05 & 10.25 & 0.77 & 26.22 \\
\hline & \multicolumn{3}{|c|}{ Bela Vista } & \multicolumn{3}{|c|}{ Laranjeiras } \\
\hline 1 & 132.65 & 9.57 & 9.57 & 145.60 & 10.50 & 10.50 \\
\hline 2 & 98.70 & 7.39 & 17.33 & 113.60 & 8.51 & 19.41 \\
\hline 3 & 82.00 & 5.95 & 22.73 & 72.00 & 5.22 & 24.03 \\
\hline 4 & 32.00 & 2.31 & 24.92 & 33.75 & 2.44 & 26.34 \\
\hline 5 & 7.25 & 0.55 & 26.57 & 9.75 & 0.73 & 28.23 \\
\hline \multicolumn{4}{|c|}{ Inoculum } & & & \\
\hline 1 & 63.50 & 4.58 & 4.58 & & & \\
\hline 2 & 35.70 & 2.67 & 7.43 & & & \\
\hline 3 & 23.50 & 1.71 & 8.90 & & & \\
\hline 4 & 14.00 & 1.01 & 9.87 & & & \\
\hline 5 & 5.30 & 0.40 & 10.70 & & & \\
\hline
\end{tabular}

SDC - Sum of the displacement of the water column; CNTP Ger. - normal conditions of temperature and pressure generated; CNTP Ac.- accumulated.

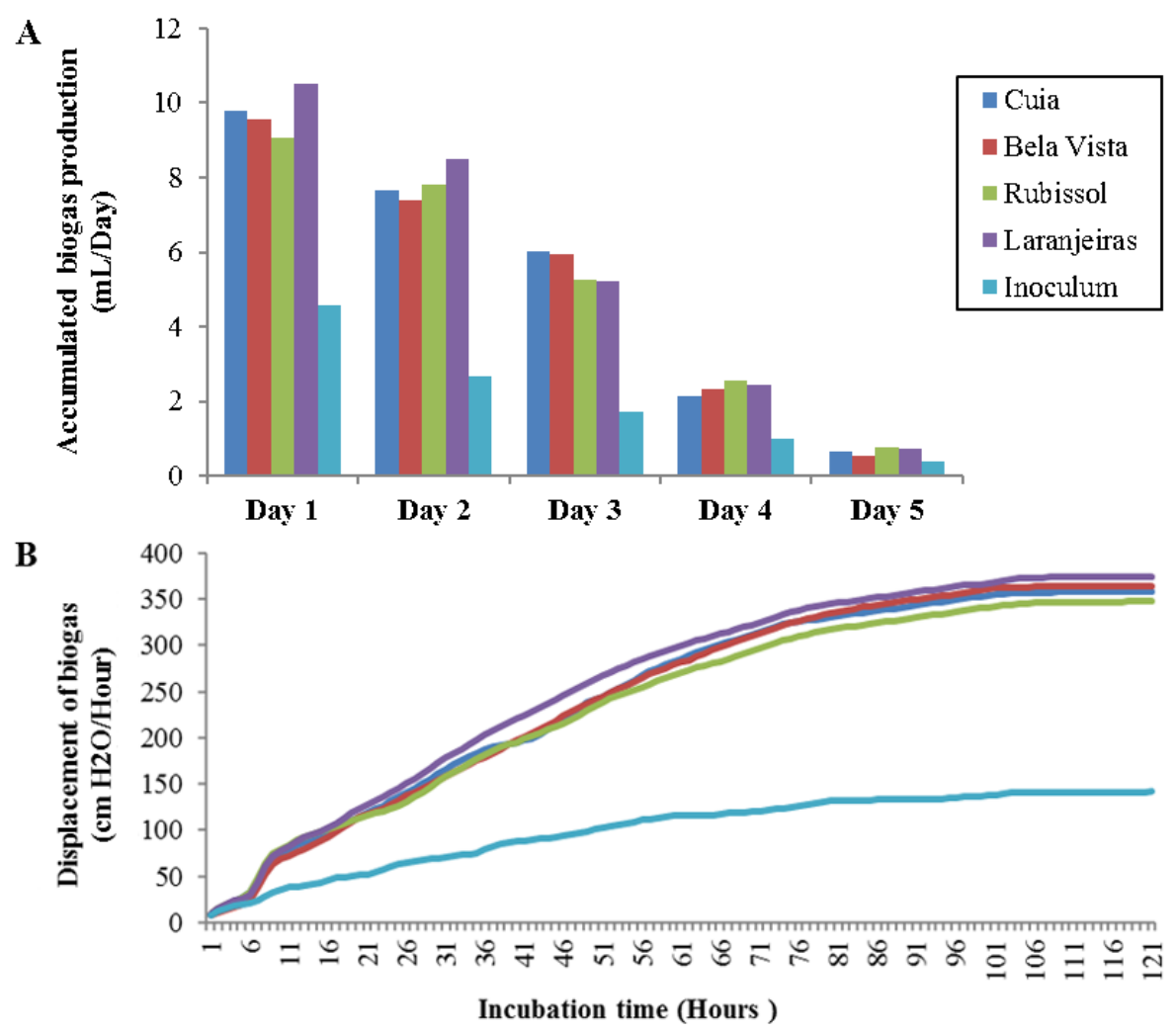

Figure 3. Profile of the medium (A) and accumulated (B) biogas production of sweet potato genotypes. 
The biogas generation peak of the sweet potato genotypes can also be explained by the absence of oxygen, as the circulation of the gaseous nitrogen stream in the headspace of the biodigesters provides anaerobiosis of the medium. The high generation observed and accumulated in the five days is due to the easily biodegradable substances of its composition, the simple sugars (Figure 3B).

According to Alves (2008), in the BMP assays it is justified that this rapid generation may be due to the small amount of substrate used, since $50 \mathrm{~g}$ of sample was used in the present experiment. It is observed that there was a correlation of the internal pressure of the flask with the atmospheric pressure, thus having different peaks of displacement in the biogas production generated. Figure 4 shows, in the first and fifth days, as an example, the values of atmospheric pressure and the normal conditions of temperature and pressure (CNTP) every six hours of evaluation for the different evaluated sweet potato genotypes.
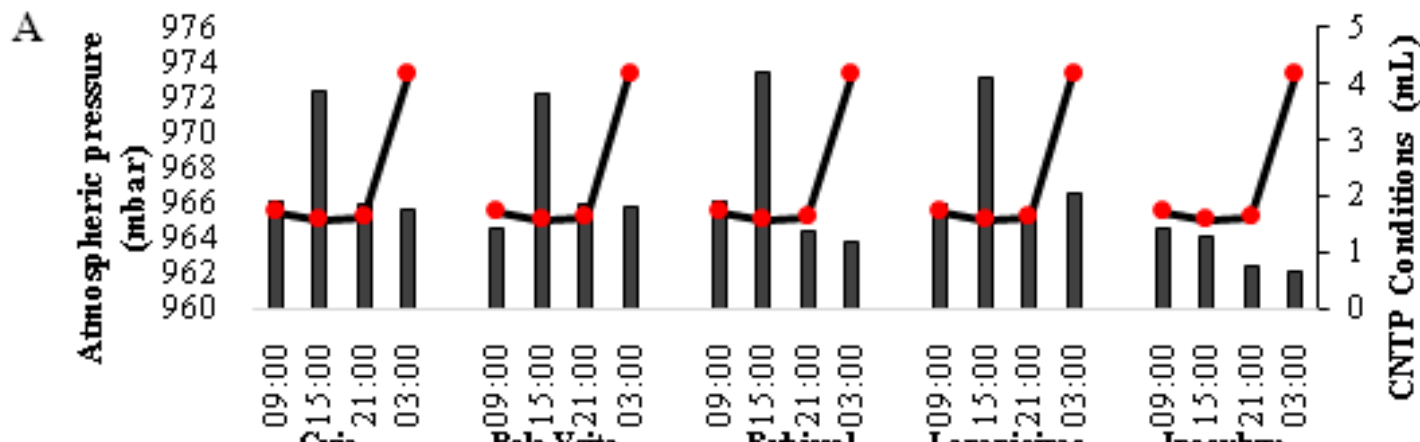

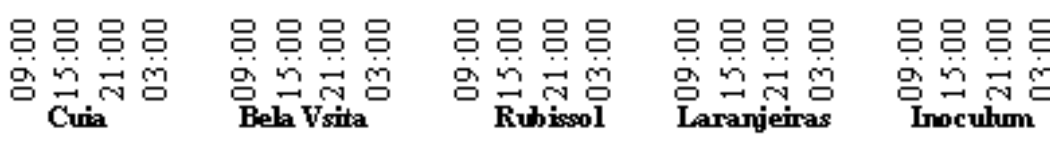
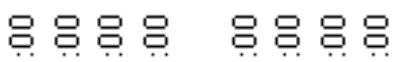

B

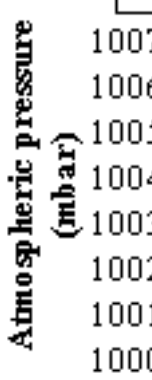

$\square$ CNTP conditions (mL)

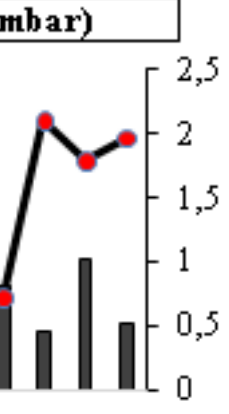

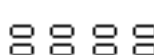

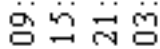

응응

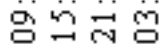

Beh Vsita
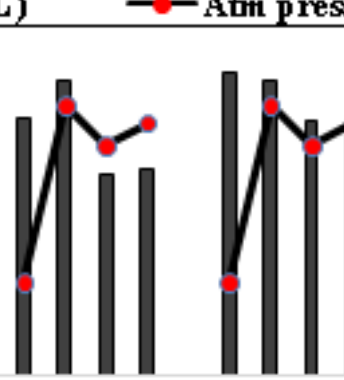

宣

$$
\text { Cuia }
$$

음응

음음

음음

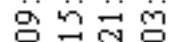

Rubissol

g음

Inocuhm

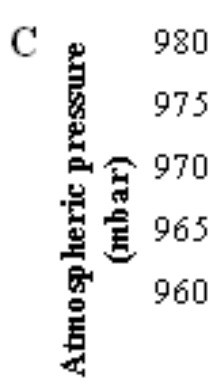

CNTP conditions (mL) - -Atm pressure (mbar)
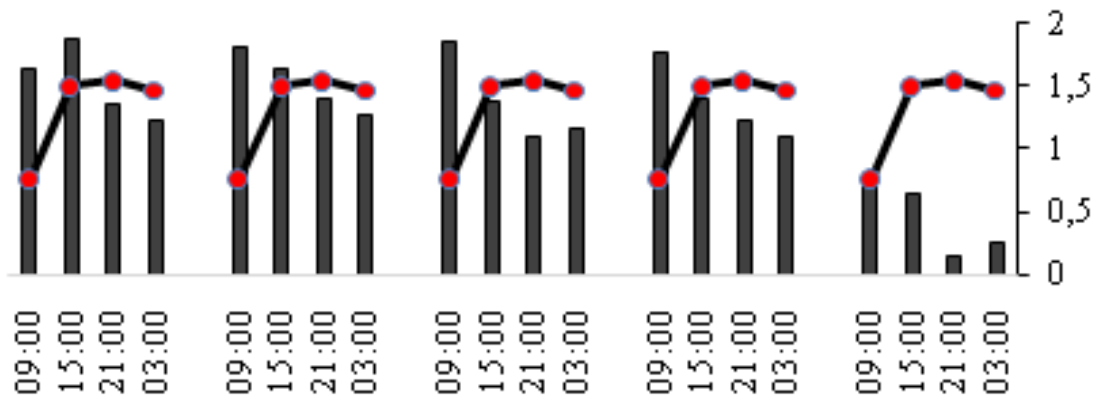

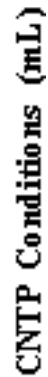

Cuia

号魚胃号

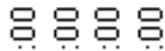

号号号号

음음

g금ำ

g금ำ

g금

gำ

Inoculum

$\square$ CNTP conditions (mL) - - Atm pressure (mbar) 

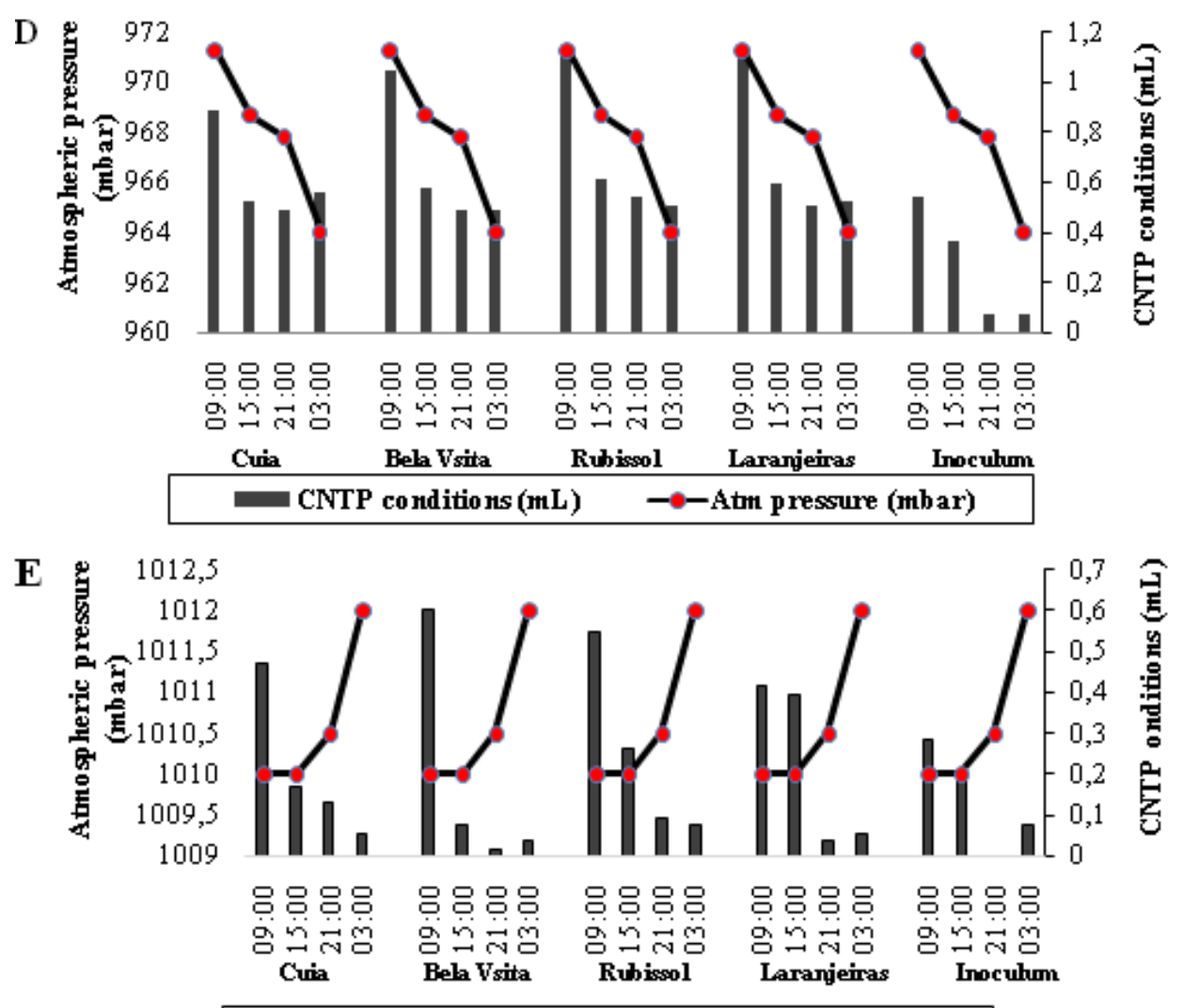

$\square$ CNTP conditio ns (mL) - - -Atm pressure (mbar)

Figure 4. Correlation of atmospheric pressure with the volume of biogas generated from sweet potato genotypes under CNTP conditions from the first day (A) to the fifth day (E).

The internal pressure of the bottles was monitored daily and converted into daily biogas generation. On the first day (Figure 4A), when the peak atm pressure was maximum, the gas production decreased. When the pressure drops, the gas increases. All cultivars and inoculum obtained the same behavior, thus observing the correlation with the volume of biogas generated.

In the second and third days (Figure 4B, 4C), this correlation was not completely observed, because the $\mathrm{pH}$ was reduced in the anaerobic biodigestion process, using simple sugars from the beginning of the process. However, the $\mathrm{pH}$ can not be monitored due to strict anaerobiosis of the flask.

On the fourth day (Figure 4D) the correlation was inversed due to the behavior of the biodigestion caused by the biochemical factors of the genotypes composition. Biodigestion and $\mathrm{pH}$ may have influenced. Then, on the fifth day (Figure 4E), biogas production decreased, but the highest peak volume occurred in the morning, although less than in previous days. Consequently, because the process was in the final stage, as the reaction rate was high, the experiment was shorter in time. If the starch reserve were available, the experimental time would be longer.

The atmospheric pressure played an important role in the interaction of the flask internal pressure with the volume of biogas generated. It was similar for the genotypes, except for the inoculum that practically obtained the production generated on the fifth day due to the difference in the proportion of the biodegradability.

Hansen et al. (2017) indicate that the determination of methane generation potential is a biological method dependent on several factors, since the inoculum used are not standardized and the matter has heterogeneous composition, which denotes the need for procedures that allow repeatability and reproducibility of the experiments. 
To verify the influenced the biogas production, principal components statistical analysis (PCA) was applied, in order to determine the spatial distribution of the physicochemical analyses and of the genotypes, decomposing the original data matrix in two other matrices: the Loading with the physical-chemical analyses and the Scores with the genotypes (Table 4). For the analysis, a preliminary selection was made for the variables that showed the highest correlation with biogas generation: $\mathrm{pH}$, humidity, biogas generated and reducing sugars.

Table 4. Correlation of the variables (Loading) and genotypes (Scores) with the principal components (PCA) of the physicochemical analysis of sweet potato genotypes.

\begin{tabular}{llll}
\hline & \multicolumn{3}{l}{ Principal Components } \\
\hline Physicochemical analysis & PCA1 & PCA2 & PCA3 \\
\hline Moisture & -0.52695 & 0.84984 & 0.0096883 \\
pH & -0.56791 & -0.80817 & 0.15598 \\
Reducing sugars & 0.93057 & -0.34601 & -0.11962 \\
Biogas & 0.91307 & 0.34043 & 0.22452 \\
\hline Genotypes & PCA1 & PCA2 & PCA3 \\
\hline Bela Vista & -0.042424 & 1.2052 & -0.3466 \\
BRS Cuia & 0.13833 & -1.7876 & -0.1517 \\
BRS Rubissol & -1.9019 & 0.2032 & 0.24101 \\
Laranjeiras & 1.806 & 0.37922 & 0.25729 \\
\hline
\end{tabular}

Figure 5 shows the distribution of the variables with PCA1 presenting $57.50 \%$ explanation of the variations and, in order of importance, the reducing sugars, $\mathrm{pH}$ and humidity. In PCA2 of $40.27 \%$, the variables with higher loadings were moisture, $\mathrm{pH}$ and reducing sugars. The sum of components 1 and 2 is equivalent to $97.77 \%$; that is, how much of the variability of the data can be explained by the PCA model.
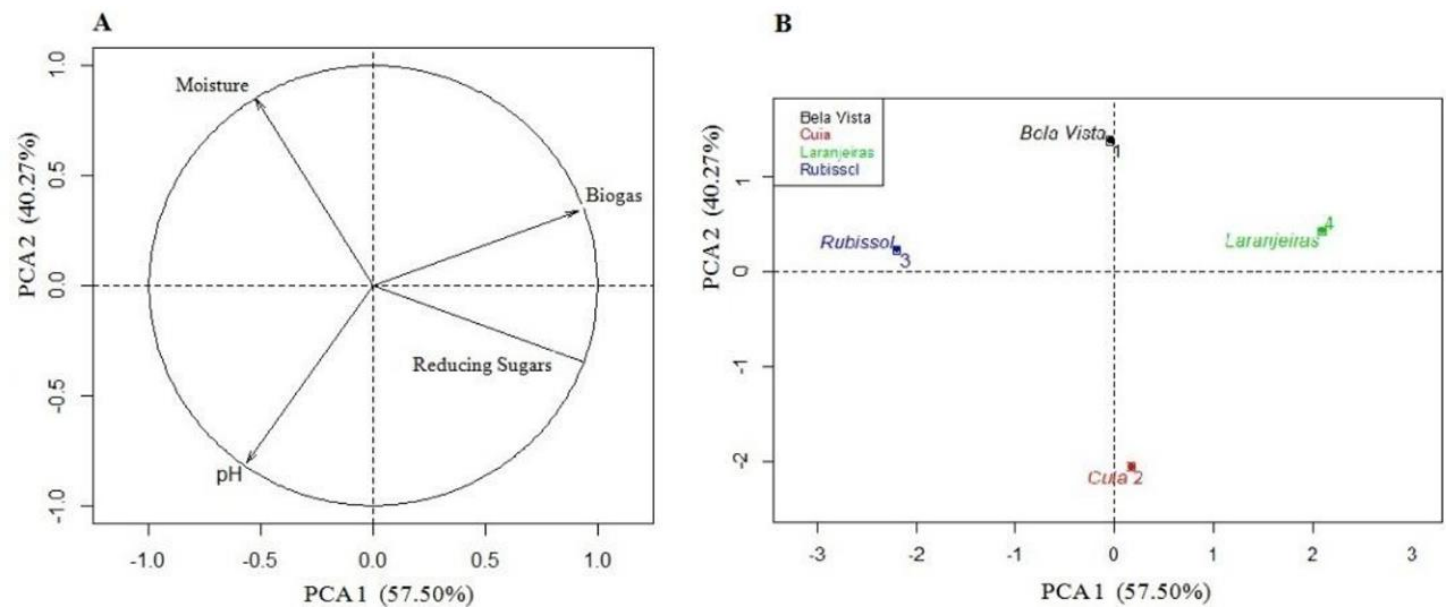

Figure 5. Loadings (A) and Scores (B) of the principal components (PCA) of the physicalchemical variables of sweet potato.

The $\mathrm{pH}$ is related to the first two principal components, and has influence on the biogas production, but did not present a significant correlation, shown by the obtuse angle formed in relation to the biogas (Figure 5A). In the case of reducing sugars and moisture, there was a correlation with the biogas production, evidenced by the acute angle.

The positive signals denote a direct correlation with the component and the negative signals mean an inverse correlation. Each line corresponds to a principal component that

\section{IPABH}

Rev. Ambient. Água vol. 14 n. 2, e2317 - Taubaté 2019 
explains a percentage of data variation, and the selected variables relate to these principal components (Crovador, 2014).

In relation to biogas production with the variables, the Laranjeiras genotype presented most significant potential to produce biogas, followed by BRS Cuia correlated with the three variables, in an intermediate region of the graph, (Figure 5B). The Bela Vista genotype and BRS Rubissol are more correlated with moisture than sugar, and have not been efficient in producing biogas. All genotypes have direct correlation with the amount of reducing sugars and moisture.

With the set of scores and loadings, it was possible to estimate the domain of each variable in each sample. The variables that caused the most biogas generation were the reducing sugars of each genotype, followed by humidity and $\mathrm{pH}$.

The BMP assays has shown the lack of compatibility of the experiments results, highlighted by Angelidaki et al. (2009). According to Elbeshbishy et al. (2012), there is no standard protocol to perform the experiment, or standardize parameters such as: equipment used, inoculum, bottle volume, $\mathrm{pH}$, headspace, among other factors. Another point that makes comparisons difficult is how the results are expressed, often in different units and incubation times.

The volume of biogas produced from the four genotypes was verified in the present test. The sweet potato genotype that stood out for the agronomic, physical-chemical characteristics and the greatest biogas generation potential were BRS Cuia and Laranjeiras. The information collected, such as the agronomic characterization of the new genotypes, viability and performance in the field, were important for possible release as a new cultivar. It was also possible to demonstrate the quality of the genotypes for energy or food destination through their physicochemical characterization.

The knowledge of biogas generation potential is a key factor in the study of the technical and economic viability of the energy obtained by biodigestion. This enables exploration of an alternative energy source, aimed at producing bioenergy with low environmental impact.

\section{CONCLUSION}

Among the evaluated sweet potato genotypes, the cultivars BRS Cuia and genotype Laranjeiras demonstrated bioenergy potential for biogas production, with 2,906.5 liters ha ${ }^{-1}$ and 2,712.4 liters $\mathrm{ha}^{-1}$, respectively.

The cultivation of the genotypes in field experiments, morphological characterization and the physico-chemical composition characteristics, mainly the amount of sugars available and the phenotypic aspects of the size and shape of their tuberous roots, demonstrate the quality of the genotypes.

The proposed procedure for the production of biogas in anaerobic biodigesters, carried out with the Biochemical Potential of Methane (BMP) test, was easy to perform and an efficient analytical method to analyze the biodegradability of organic materials.

\section{REFERENCES}

ALVES, I. R. F. S. Análise experimental do potencial de geração de biogás em resíduos sólidos urbanos. 2008. 118 f. Dissertação (Mestrado) - Programa de Pós-Graduação em Engenharia Civil, CTG - Centro de Tecnologia e Geociências, Universidade Federal de Pernambuco, Recife, 2008.

ALZATE, M. E. et al. Biochemical methane potential of microalgae: influence of substrate to inoculum ratio, biomass concentration and pretreatment. Bioresource Technology, v. 123, p. 488-494, 2012. https://doi.org/10.1016/j.biortech.2012.06.113 
ANGELIDAKI, I. et al. Defining the biomethane potential (BMP) of solid organic wastes and energy crops: a proposed protocol for batch assays. Water Science \& Technology, v. 59, n. 05, p. 927-934, 2009. https://doi.org/10.2166/wst.2009.040

ASSOCIATION OF OFFICIAL ANALYTICAL CHEMISTS - AOAC. Official methods of analysis. 18. ed. Washington: AOAC, 2007. 3000 p.

AZEVEDO, F. G. Estudo das condições ambientais para produção de Biogás a partir de glicerol co-produto do Biodiesel. 2010. 88p. Dissertação (Mestrado em Engenharia Química) - Universidade Federal de Pernambuco, Recife, 2010.

BORBA, A. M.; SARMENTO, S. B. S.; LEONEL, M. Efeito dos parâmetros de extrusão sobre as propriedades funcionais de extrusados da farinha de batata-doce. Ciência e Tecnologia de Alimentos, v. 25, n. 4, p. 835-843, 2005.

BORÉM, A.; MIRANDA, G.V. Melhoramento de plantas. Viçosa: UFV, 2005. 525 p.

BRASIL. Ministério da Saúde. Agência Nacional de Vigilância Sanitária. Resolução - CNNPA no 12 1978. Diário Oficial [da] União, 24 jul., 1978.

BRASIL. Secretaria Nacional de Saneamento Ambiental. Probiogás. Tecnologias de digestão anaeróbia com relevância para o Brasil: substratos, digestores e uso de biogás.et al. Brasília, DF: Ministério das Cidades, 2015. 83 p.

CECCHI, H. M. Fundamentos teóricos e práticos em análises de alimentos. 2. ed. Campinas: Editora da Unicamp, 2003. 207 p.

CHITARRA, M. I. F.; CHITARRA, A. B. Pós-colheita de frutos e hortaliças. 2. ed. Lavras: ESAL, 2005. 783 p.

CROVADOR, M. I. C. Potencial de geração de biogás a partir da fração orgânica de resíduos sólidos urbanos. 2014. 103 p. Dissertação (Mestrado) - Universidade Estadual do Oeste do Paraná Programa de Pós-Graduação em Bioenergia, Guarapuava, PR.

DEGANUTTI, R. et al. Biodigestores rurais: modelo indiano, chinês e Batelada. Procedings of the 4th Encontro de Energia no Meio Rural, n. 4, 2002.

ELBESHBISHY, E.; NAKHLA, G.; HAFEZ, H. Biochemical methane potential (BMP) of food waste and primary sludge: influence of inoculum pre-incubation and inoculum source. $\begin{array}{llllll}\text { Bioresource } & \text { Technology, } & \text { v. } & 110, & \text { p. } & 18-25,\end{array}$ https://doi.org/10.1016/j.biortech.2012.01.025

GUERI, M. V. D. et al. Digestão anaeróbia de resíduos alimentares utilizando ensaios bmp. $\begin{array}{lllllllll}\text { BIOFIX Scientific Journal, } & \text { v. } 3, \quad \text { n. } & 1, & \text { p. } & 08-16,\end{array}$ http://dx.doi.org/10.5380/biofix.v3i1.55831

HARRIES, C. R. et al. Development of a biochemical methane potential (BMP) test and application to testing of municipal solid waste samples. In: INTERNATIONAL WASTE MANAGEMENT AND LANDFILL SYMPOSIUM, 8., Cagliari, Italy. Proceedings Sardinia[...] Cagliari: CISA, 2001. v.1, p. 579-588.

HASSAN, M. et al. Batch and semi-continuous anaerobic co-digestion of goose manure with alkali solubilized wheat straw: a case of carbon to nitrogen ratio and organic loading rate regression optimization. Bioresour Technol, p. 230:24-32, 2017. https://doi.org/10.1016/j.biortech.2017.01.025 
INSTITUTO ADOLFO LUTZ - IAL. Normas Analíticas do Instituto Adolfo Lutz. Vol. 1: Métodos físicos e químicos para análise de alimentos. 3 ed. São Paulo: IMESP, 2008. p.1020.

KOHYAMA, K.; NISHINARI, K. Cellulose derivatives effects on gelatinization and retrogradation of sweet potato starch. Journal of Food Science, v. 57, n. 1, p. 128131, 1992. https://doi.org/10.1111/j.1365-2621.1992.tb05439.x

LIMA, U. A.; BASSO, L. C.; AMORIM, H. V. Produção de etanol. In: SCHMIDELL, W.; LIMA, U. A.; AQUARONE, E.; BORZANI, W. (Coords.). Biotecnologia Industrial: Processos Fermentativos e Enzimáticos, v. 3, capítulo 1. São Paulo: Edgard Blücher, 2001. p. 1-43.

MCKENDRY, P. Energy production from biomass: overview of biomass. Bioressource Technology, v. 83, p. 37- 46, 2002. https://doi.org/10.1016/S0960-8524(01)00118-3

MIRANDA, J. E. C. et al. A cultura da batata-doce. Brasília: EMBRAPA, 1995. 94 p.

SILVA, J. B. C. et al. Cultura da batata-doce. Brasília: EMBRAPA, 2008. Disponível em: http://www.cnph.embrapa.br/sistprod/batatadoce. Acesso em: 15 jan. 2016.

SILVA, J. O. V.; ALMEIDA, M. F.; ALVIM-FERRAZ, M. da C.; DIAS, J. M. Integrated production of biodiesel and bioethanol from sweet potato. Renewable Energy, v. 124, p. 114-120, 2018. https://doi.org/10.1016/j.renene.2017.07.052

SILVEIRA, M. A. Batata-doce: Uma nova alternativa para a produção de etanol. Brasília: IEL, 2008. p. 109-122.

SCHIRMER, W. N.; JUCÁ, J. F. T.; SCHULER, A. R. P.; HOLANDA, S.; JESUS, L. L. Methane production in anaerobic digestion of organic waste from Recife (Brazil) Landfill: 102 evaluation in refuse of different ages. Brazilian Journal of Chemical Engineering, v. 31, n. 02, p. 373-384, 2014. http://dx.doi.org/10.1590/01046632.20140312s00002468

STATHERS, T. et al. Tudo o Que Sempre Quis Saber Sobre a Batata-doce: Manual de capacitação CdF - Alcançando Agentes de Mudança. Nairobi: Centro Internacional da Batata, 2013. 436 p.

XAVIER, C. A. N. et al. Parâmetros de dimensionamento para biodigestores batelada operados com dejetos de vacas leiteiras com e sem uso de inóculo. Engenharia Agrícola, v. 30, n. 2, p. 212-223, 2010. https://doi.org/10.1590/S0100-69162010000200003

XUMENG, G. et al. Biogas energy production from tropical biomass wastes by anaerobic digestion. Bioresource Technology, n. 169, p. 38-44, 2014. https://doi.org/10.1016/j.biortech.2014.06.067

YU, Z.; SCHANBACHER, F. L. Production of Methane Biogas as Fuel Through Anaerobic Digestion. New York: Springer, 2010. p.105-127.

ZHANG, et al. Anaerobic digestion performance of sweet potato vine and animal manure under wet, semi-dry, and dry conditions. AMB Express, v. 8, p. 45, 2018. https://doi.org/10.1186/s13568-018-0572-9 